\title{
Research about the Advanced Manufacturing Services with Empirical and Development Status in Guangxi: Based on the Theory of Input-Output
}

\author{
Zhi-Ping LU ${ }^{1, a}$, Yuan-Yuan YAN ${ }^{1, b,{ }^{*}}$, Xiang WU ${ }^{1, c}$ \\ ${ }^{1}$ School of Management, Guangxi University of Science and Technology, Liuzhou, P.R. China \\ a404840561@qq.com, b1198033660@qq.com, '542460556@qq.com \\ ${ }^{*}$ Corresponding author
}

Keywords: Advanced manufacturing, Service-oriented, The theory of input-output.

\begin{abstract}
This paper describes the introduction of advanced manufacturing and manufacturing services in China and the global. Basis on that, we analyze the development of the advanced manufacture services with models and indicators. By using the theory of input-output to analyze the coefficient proportion of investment in advanced manufacturing services input and manufacturing sub-sector input of Guangxi, we can conclude something from it.
\end{abstract}

\section{Introduction}

Advanced manufacturing, which is recently proposed, is a concept of the domestic economy. It is mainly about innovation of technical, management, industry, development patterns and other aspects. With the development of the manufacturing sector, more and more enterprises begin to improve service in the proportion of its business operations. This phenomenon is called "manufacturing services" by economists. It reflects the change in the terms of manufacturing enterprise integration services to sell products [1].

There are two levels of manufacturing services in this paper. The first one is so-called the service of input, which is to say the elements of service play an increasingly important role in the total investment of the manufacturing sector. The second one is the service of business, which is also known as output of services, is all the products and services output occupy an increasingly important position in the manufacturing sector. Manufacturing services is the process of manufacturing enterprises from producers to who provide full-service [2]. The output ratio of the proportion of investment business service elements and service offerings continue to rise in this process.

\section{The status of advanced manufacturing services in China and foreign countries}

Based on the listed companies on the global database (OSIRIS database), Nelly analyzed that the proportion of service among China's listed companies in 2007 was only $2 \%$, which reached over $20 \%$ in 2009[4].But US-listed company's advanced manufacturing services was more than 50\% in 2009 [3].According to the situation from 2012 annual reports of listed companies in China, the proportion of 15 representative companies listed companies advanced manufacturing services business total revenue is generally not high, only one exceeds $20 \%$, but still 6 companies are less than $10 \%$.All around the world, such as IBM, Dell, GE, Nike and many other companies are in transition to a service-based model from a manufacturing model. For example, services revenue of IBM in 2011 accounted for $82.1 \%$ of the total revenue, profit before tax services business accounted for $92.9 \%$ of the total profit [4]. In summary, the level of advanced manufacturing services in China is generally lower.

Therefore, this paper analyzes these two aspects of the research. By modeling and quantitative indicators to analysis advanced manufacturing service input coefficient, manufacturing input 
coefficient and the proportion of intermediate inputs by industry of Guangxi, we provide a reference for advanced manufacturing services to enhance the level of Guangxi.

\section{Data selection and model building}

Based on the newest the division regulations of three kinds of industries in China, we can divide the services into 16 industries, and the manufacturing was divided into 17. In this paper, the raw data come from input-output tables of 42 sectors in 2002\&2007. By calculating the coefficient of directly consumption and completely consumed, to analyze the level of advanced manufacturing services and evolution in Guangxi.

The theory of input-output is raised in the 1930s by Leontief, who is the well-known economist in the America, as well as the Nobel laureate. The method is used to analysis economic aspects problems with numbers [5].The various sectors of the national economy includes investment into the physical inputs and services. Input-output coefficients are the important tools of input-output analysis. Direct consumption coefficient and complete consumption coefficient can reflect the interdependencies between the various sectors of the national accounts. Direct consumption coefficient refers to the total output of the unit production process j-product (or industry) sector of the direct consumption of the $\mathrm{i}$-product division of goods or services. Direct consumption coefficient is generally indicated by the letter A. Complete consumption coefficient is the sum of the i-product division products or services directly or indirectly consume consumption when the j-products division to provide a unit for each end-use. Complete consumption coefficient is generally indicated by the letter $\mathrm{B}$.

Direct consumption coefficient is calculated as follows:

$$
a_{i j}=x_{i j} / x_{j},(i, j=1,2,3 \ldots n)
$$

Where: $x_{i j}$ stands for the units of a product (or industry) sector total output; $x_{j}$ stands for the value of the product division of goods or services.

Complete consumption coefficient matrix can be obtained direct consumption coefficient matrix operations. The formula is:

$$
\mathrm{B}=(\mathrm{I}-\mathrm{A})^{-1}
$$

Where:I was of the same order unit matrix A, $(\mathrm{I}-\mathrm{A})$ is the famous Leontief matrix.

\section{The analysis of advanced manufacturing service input coefficients in Guangxi}

In order to meet the needs of the analysis, we have been processed the $2002 \& 2007$ original input-output tables in Guangxi and the National. We merged the 42 sectors into six major industries, which are agriculture, mining, manufacturing, water and electricity production, supply, construction, services, and got the new input-output tables[6] (Table 1).

Based on Table 1, we can further calculate the coefficient consumed directly completely in Guangxi and the whole country (Table 2).

In recent years, we can know the total investment in the manufacturing services increased in Guangxi from 2002 to 2007 from Table 1. Thus, the trend of advanced manufacturing services in Guangxi is upward. However, the tendency of manufacturing services into the proportion of Guangxi is go down, which can be seen from Table 2.The coefficient directly consumed fells from 
0.1887 to 0.0963 in 2002 , and the complete consumption coefficient services fell from 0.5543 to 0.2686 in that year, which is consistent with the national tendency. Compared with the national average, the investment in Guangxi manufacturing services is slightly less [7].

Table1 Invested in 2002\& 2007 after the merger of industry output tables in Guangxi

\begin{tabular}{|c|c|c|c|c|c|c|c|}
\hline 2002 & $\begin{array}{c}\text { Agricultur } \\
\mathrm{e}\end{array}$ & $\begin{array}{l}\text { Mining } \\
\text { industry }\end{array}$ & $\begin{array}{l}\text { Manufact } \\
\text { uring }\end{array}$ & $\begin{array}{c}\text { Water } \\
\text { and } \\
\text { electricity } \\
\text { industry }\end{array}$ & $\begin{array}{l}\text { Building } \\
\text { industry }\end{array}$ & Services & $\begin{array}{c}\text { Total } \\
\text { output }\end{array}$ \\
\hline Agriculture & 1415955 & 7204 & 1429734 & 0 & 55728 & 320023 & 9446702 \\
\hline Mining industry & 382 & 59120 & 1355153 & 184104 & 325431 & 5671 & 1278450 \\
\hline Manufacturing & 1508286 & 171522 & 8108259 & 46206 & 3187242 & 2139977 & 21424904 \\
\hline $\begin{array}{l}\text { Water and electricity } \\
\text { industry }\end{array}$ & 40208 & 64725 & 906608 & 75538 & 39504 & 544577 & 1443535 \\
\hline Building industry & 1830 & 1619 & 9017 & 276 & 0 & 203455 & 6268375 \\
\hline Services & 366104 & 322829 & 4043331 & 454160 & 1012434 & 4454228 & 17555851 \\
\hline Value Added & 6113937 & 651432 & 5572802 & 683251 & 1648036 & 9887919 & \\
\hline Total investment & 9446702 & 1278450 & 21424904 & 1443535 & 6268375 & 17555851 & \\
\hline 2007 & $\begin{array}{c}\text { Agricultur } \\
\mathrm{e}\end{array}$ & $\begin{array}{l}\text { Mining } \\
\text { industry }\end{array}$ & $\begin{array}{l}\text { Manufact } \\
\text { uring }\end{array}$ & $\begin{array}{c}\text { Water } \\
\text { and } \\
\text { electricity } \\
\text { industry }\end{array}$ & $\begin{array}{l}\text { Building } \\
\text { industry }\end{array}$ & Services & $\begin{array}{c}\text { Total } \\
\text { output }\end{array}$ \\
\hline Agriculture & 2952739 & 5095 & 5268992 & 0 & 38412 & 433843 & 20262157 \\
\hline Mining industry & 291 & 131258 & 4284059 & 1219126 & 151750 & 5215 & 2321480 \\
\hline Agriculture & 2952739 & 5095 & 5268992 & 0 & 38412 & 433843 & 20262157 \\
\hline Mining industry & 291 & 131258 & 4284059 & 1219126 & 151750 & 5215 & 2321480 \\
\hline Manufacturing & 3961854 & 338592 & 22500275 & 205929 & 6602614 & 5164947 & 56614690 \\
\hline $\begin{array}{c}\text { Water and electricity } \\
\text { industry }\end{array}$ & 113349 & 197994 & 2112859 & 2902492 & 135277 & 768012 & 7656368 \\
\hline Building industry & 0 & 546 & 24852 & 2451 & 54663 & 203232 & 12460596 \\
\hline Services & 820428 & 318360 & 5450447 & 695189 & 2126079 & 6052974 & 35518237 \\
\hline Value Added & 12413497 & 1329635 & 16973205 & 2631180 & 3351800 & 22890015 & \\
\hline Total investment & 20262157 & 2321480 & 56614690 & 7656368 & 12460596 & 35518237 & \\
\hline Agriculture & 2952739 & 5095 & 5268992 & 0 & 38412 & 433843 & 20262157 \\
\hline Mining industry & 291 & 131258 & 4284059 & 1219126 & 151750 & 5215 & 2321480 \\
\hline
\end{tabular}

Table2 The comparison of coefficient in advanced manufacturing and the services sector between Guangxi and the national

\begin{tabular}{|c|c|c|c|c|}
\hline \multirow{2}{*}{ Years Index } & \multicolumn{2}{|c|}{ Guangxi } & \multicolumn{2}{c|}{ Nationwide } \\
\cline { 2 - 5 } & $\begin{array}{c}\text { A direct consumption } \\
\text { coefficient }\end{array}$ & $\begin{array}{c}\text { Complete } \\
\text { consumption } \\
\text { coefficient }\end{array}$ & $\begin{array}{c}\text { A direct } \\
\text { consumption } \\
\text { coefficient }\end{array}$ & $\begin{array}{c}\text { Complete } \\
\text { consumption } \\
\text { coefficient }\end{array}$ \\
\hline 2002 & 0.1887 & 0.5543 & 0.1216 & 0.3865 \\
\hline 2007 & 0.0963 & 0.2686 & 0.0835 & 0.3396 \\
\hline
\end{tabular}

The manufacturing to the service sector completely consumed coefficient in Guangxi is lower than the national, which is 0.7098 in 2007. It is optimistic that Guangxi manufacturing services for directly consumption coefficient is higher than the national, which is 0.0128 in 2007 . With the pace of industrial transformation and upgrading, Guangxi will gradually narrow the gap with other parts of the country on the coefficients completely consumed. 


\section{The analysis of coefficients about Manufacturing Sector service input in Guangxi}

There are 17 manufacturing industries in the input-output tables of 42 sectors in Guangxi during 2002\&2007. By calculating, we can get the coefficients of manufacturing sub-sectors of services in Guangxi (Table 3).

Table 3 The coefficients of manufacturing sub-sector service input in Guangxi

\begin{tabular}{|c|c|c|}
\hline Years & $\mathbf{2 0 0 2}$ & $\mathbf{2 0 0 7}$ \\
\hline Manufacturing & 0.1887 & 0.0963 \\
\hline Textile industry & 0.1798 & 0.0955 \\
\hline Food manufacturing and tobacco processing industry & 0.1555 & 0.0553 \\
\hline Textile, leather and feather products industry & 0.1738 & 0.0472 \\
\hline Wood processing and furniture manufacturing & 0.1434 & 0.0614 \\
\hline Paper printing and Educational and Sports Goods & 0.1625 & 0.0794 \\
\hline Chemical Industry & 0.1090 & 0.0260 \\
\hline Petroleum processing, coking and nuclear fuel processing industry & 0.2005 & 0.0991 \\
\hline Non-metallic mineral products industry & 0.2018 & 0.1399 \\
\hline Fabricated Metal & 0.1831 & 0.1098 \\
\hline Transportation Equipment Manufacturing & 0.1378 & 0.0833 \\
\hline Electrical machinery and equipment manufacturing & 0.2144 & 0.0974 \\
\hline Communications equipment, computers and other electronic equipment & 0.2180 & 0.0785 \\
\hline manufacturing & 0.2123 & 0.1118 \\
\hline
\end{tabular}

Based on the analysis, we can see that the services input coefficients of chemical industry, non-metallic mineral products, transport equipment manufacturing and other manufacturing services, although decline, which is still greater than that of manufacturing services. As the service into scrap waste industry is low, it is rose to 0.0326 in 2007, which shows an upward trend. Food manufacturing and tobacco processing industry and other manufacturing services have the higher investment but a downward trend. It is worth noting.

\section{The analysis of services sub-sector share of intermediate inputs in manufacturing in Guangxi}

Intermediate inputs from the service sector share of the industry in manufacturing point of view, the most increase were tourism, health, social security and social welfare, an increase of $0.1522 \%$, $0.1357 \%$, which compared with 2002. The dropped mostly were Information transmission and computer services, transportation and warehousing, finance and insurance which were less $6.0370 \%$, $1.2757 \%, 1.0157 \%$ compared with 2002 (Table 4).

Based on the analysis of table 4, among the 16 services sub-sectors, there were four intermediate inputs into manufacturing industries in specific gravity greater than 0.5 in 2007 , which were transportation and warehousing, wholesale and retail trade, finance and insurance, leasing and business services. There were also 11 manufacturing industries in the relatively low proportion of intermediate inputs. However the proportion of tourism, health, social security and social welfare were on the rise. While, the postal services, information transmission, computer services and software industry, accommodation and catering, real estate, scientific career, other social services, 
culture, sports and the proportion of those eight begin to decline, which should be paid attention to.

Table 4 The proportion of intermediate inputs in manufacturing a variety of services

\begin{tabular}{|c|c|c|c|c|c|}
\hline \multirow[b]{2}{*}{ Industry } & \multicolumn{2}{|c|}{ Intermediate service inputs } & \multicolumn{3}{|c|}{$\begin{array}{l}\text { Manufacturing accounted for the } \\
\text { proportion of intermediate inputs }\end{array}$} \\
\hline & $\begin{array}{l}2002(\text { Ten } \\
\text { thousand) }\end{array}$ & $\begin{array}{l}2007(\text { Ten } \\
\text { thousand) }\end{array}$ & $\begin{array}{l}2002 \\
(\%)\end{array}$ & $\begin{array}{c}2007 \\
(\%)\end{array}$ & $\begin{array}{c}\text { Rise/Drop } \\
(\%)\end{array}$ \\
\hline Intermediate service inputs & 17555851 & 35518237 & & & \\
\hline $\begin{array}{l}\text { Service in the middle of } \\
\text { manufacturing inputs }\end{array}$ & 4043331 & 5450447 & 18.8721 & 9.6273 & -9.2448 \\
\hline Transportation and warehousing & 764737 & 1298581 & 3.5694 & 2.2937 & -1.2757 \\
\hline Postal Services & 7010 & 5571 & 0.0327 & 0.0098 & -0.0229 \\
\hline $\begin{array}{l}\text { Information transmission, computer } \\
\text { services and software industry }\end{array}$ & 1337351 & 116099 & 6.2420 & 0.2051 & -6.0370 \\
\hline Wholesale and retail trade & 992497 & 2571027 & 4.6324 & 4.5413 & -0.0912 \\
\hline $\begin{array}{l}\text { Accommodation and Catering } \\
\text { Services } \\
\end{array}$ & 113774 & 143449 & 0.5310 & 0.2534 & -0.2777 \\
\hline Finance and insurance & 426350 & 551604 & 1.9900 & 0.9743 & -1.0157 \\
\hline Real Estate & 27663 & 26400 & 0.1291 & 0.0466 & -0.0825 \\
\hline Leasing and Business Services & 229102 & 359062 & 1.0693 & 0.6342 & -0.4351 \\
\hline Tourism & 1219 & 89386 & 0.0057 & 0.1579 & 0.1522 \\
\hline Scientific career & 39997 & 60861 & 0.1867 & 0.1075 & -0.0792 \\
\hline Integrated Technical Services & 13996 & 11295 & 0.0653 & 0.0200 & -0.0453 \\
\hline Other social services & 41722 & 87466 & 0.1947 & 0.1545 & -0.0402 \\
\hline Education & 12499 & 16193 & 0.0583 & 0.0286 & -0.0297 \\
\hline $\begin{array}{l}\text { Health, social security and social } \\
\text { welfare }\end{array}$ & 5439 & 91173 & 0.0254 & 0.1610 & 0.1357 \\
\hline Culture, Sports and Entertainment & 29974 & 22282 & 0.1399 & 0.0393 & -0.1005 \\
\hline Public and Social Organization & 0 & 0 & 0 & 0 & 0 \\
\hline Intermediate inputs into manufacturing & 21424904 & 56614690 & 100. 00 & 100. 00 & 100. 00 \\
\hline
\end{tabular}

\section{The conclusions}

Based on all above, we empirical and make research into the advanced manufacturing services in Guangxi, and we can draw the following points:

1. The whole investment in advanced manufacturing services in Guangxi has risen significantly, but the proportion is still insufficient. The coefficient of complete consumption is lower than the national average. But with the high speed of industrial restructuring and upgrading in Guangxi, the proportion of investment in manufacturing services gradually increased in 2007, and the gap reduced when compared with the rest of the country .

2. The service level of commitment in manufacturing industries is much different in Guangxi. There is a higher proportion of investment in the traditional manufacturing and services than advanced manufacturing services.

3. The service trades in the production of manufacturing investment degree are different in Guangxi. The proportion of traditional service industry accounts for manufacturing intermediate input is higher than the emerging service industry.

\section{Acknowledgement}

We sincerely thank the guest editors and the anonymous referees for their valuable suggestions and comments. This research is supported by the Ministry of education of Humanities and social science research projects (No.10YJA630162) and the Guangxi Department of education research project 
(No.YB2014217).

\section{References}

[1] B. Tether, J. Howells, Changing understanding of Innovation in Services, J. Innovation in Services. 9(2007)21- 60 .

[2] A. Radding, How IBM is applying science, J. Consulting Magazine.3 (2006)10-19.

[3] F.R. Lusch, S.L. Vargo, The Service dominant Logic of Marketing: Dialog, debate and directions, M. Armonk, NY: M.E. Sharpe, 2006.

[4] A. Neely, Exploring on the Financial Consequences of this Civilization of Manufacturing, J. Operations Management Research.2 (2008)103-118.

[5] An Xiaopeng,The Road-map of Manufacturing Services: Mechanism, Mode and Select, M. Beijing: Commercial Press, 2012.(in Chinese)

[6] C. Gonross, Service logic revisited: who creates value? And who co-creates? J. European Business Review. 4 (2008)298 -314.

[7]A.B. Engin, Comparative Analysis for Periodical and Random Servicing Systems Considering different Working Circus-stances: a Textile Application, J. Journal of Manufacturing Systems.4(2009)89-97. 